\section{Report of the Smithsonian Institution}

THe annual report of the Board of Regents of the Smithsonian Institution for the year ended June 30 , 1958, contains besides the Secretary's report and those of the several branches, the general appendix, comprising a miscellaneous selection of papers, some of which are original (pp. $x+559+107$ plates. Pub. lication 4354. Washington, D.C.: Government Printing Office, 1959. 3.75 dollars). Among those not available elsewhere or not easily accessible to British readers may be mentioned those of Farrington Daniels on "The Sun's Energy"; D. Cox and M. Stoiko, "Rocketry"; D. S. Jenkins, "Fresh Water for Arid Lands" ; Prof. H. E. Suess, "The Abundance of the Chemical Elements"; Prof. K. E. Bullen, "Earthquakes and Related Sources of Evidence on the Earth's Internal Structure"; P. B. Sears's Condon Lecture, "The Ecology of Man"; E. F. Knipling, "Screw-worm Eradication : Concepts and Research leading to the Sterile-Male Method"; W. L. Schmitt, "Narrative of the 1958 Smithsonian-Bredin Caribbean Expedition" ; A. I. Hallowell, "The Backwash of the Frontier : the Impact of the Indian on American Culture"; Prof. R. E. Crist, "Accultura. tion in the Guajira"; N. M. Judd, "The Braced-up Cliff at Pueblo Bonito" ; H. G. McCurdy, "The Childhood Pattern of Genius" ; and A. N. B. Garvan, "The New England Porringer : an Index of Custom".

\section{The National Research Council (Canada)}

The "Review of the National Research Council" (Canada), 1959, describes the work of the Council during the year ended December 31, 1958, but includes some later work (pp. 337. NRC No. 5251. Ottawa: Queen's Printer, 1959. 75 cents). It contains reports of the directors of divisions and heads of sections, as well as accounts of the work of the Council's committees and a list of scientific staff. Supplementing the previously published annual report of the Council, it is distributed to scientists, research institutions and other persons or organizations who require more detailed information.

\section{Journal of Electroanalytical Chemistry}

THE appearance of a new journal cannot nowadays be greeted with unqualified enthusiasm. However, the splintering of the sciences into highly specialized parts seems to be inevitable, and literature research within each speciality would certainly be simplified if the workers concerned could be persuaded to publish their contributions in the particular journal devoted to their subject. A new Journal of Chromatography appeared in 1958, and its success has encouraged the publishers (Elsevier, Amsterdam) to bring out an accompanying Journal of Electroanalytical Chemistry. Both these fields are of great importance in modern analytical chemistry, and hitherto research in both of them has been spread throughout the chemical literature. The format of the new Journal is convenient, the editors (Profs. G. Charlot, J. O'M. Bockris and C. N. Reilley) are distinguished, the editorial board contains most of the internation. ally known electrochemists, and the contents of the first issue set a high standard. Quite generally, the publishers are to be congratulated on the new venture. Nevertheless, the increasing flow of papers poses many problems; the growing sentiment is that the necessity is not for new journals but for a more critical approach in the editing and refereeing of papers in existing journals. The essence of too many papers in the general literature could be conveyed in two lines rather than two pages. Only time will show whether or not this new Journal will fulfil its purpose. If the bulk of electroanalytical papers can be diverted into it and if the editors make sure that the initial high standard is maintained, then the Journal will indeed be a worthy contribution to the literature.

\section{Biochemical and Biophysical Research Communications}

This new journal aims at securing rapid publication of short but well-documented communications in all fields of experimental biology (Vol. 1, No, 1 (July 1959). Pp. 44. Published monthly. Subscription rates ( 1 volume, 6 issues): Institutional subscribers 12 dollars; 85s. 6d. Private subscribers certifying that the volume will be for personal use only, 6.50 dollars; 46s. (New York and London: Academic Press, Inc., 1959.)) The scope of the communications so far published is not unlike that of many of the biochemical "Letters" to Nature. The papers are reproduced directly from the typescript, and in spite of differences in size of type, the appearance of the pages is pleasing and the quality of reproduction of typescript and figures is excellent. So far, the number of communications per monthly part has ranged from about ten to twenty, each of about four double-spaced typeseript pages. The aim of quick publication is certainly being achieved: for example, in the January 1960 number, the earliest paptr was received on November 23, 1959, and the latest, on January $\bar{i}$, 1960.

\section{Cost of Scientific Periodical Publications}

Mr. K. W. Humphreys, honorary secretary of the Standing Conference of National and University Libraries, and Mr. H. D. Barry, secretary of the Library Association, have written referring to the high cost of scientific periodicals. They have prepared the following table of periodicals which are comparable in that none has many advertisements and they are similar in matter per page; they have arranged them in order of the price per page:

\begin{tabular}{|c|c|c|c|}
\hline Title & Source & Publisher & $\begin{array}{c}\text { Price } \\
\text { per }\end{array}$ \\
\hline Biochemical Journal & U.K. & Camb. Univ. Press & $\begin{array}{c}\text { page } \\
0 \cdot 75 d\end{array}$ \\
\hline Society & U.K. & Chemical Society & $1 \cdot 0$ \\
\hline Chemical Reviews & U.S.A. & American Chemical society & $1 \because 2$ \\
\hline Journal of Soil Science & U.K. & Oxford Univ. Press & $1 \cdot 3$ \\
\hline Information and Control & & Academic Press & $2 \cdot 0$ \\
\hline $\begin{array}{l}\text { Philosophical Magazine, } \\
\text { Biochemica }\end{array}$ & $\begin{array}{l}\text { U.K. } \\
\text { Duteh }\end{array}$ & Taylor and Franeis & $\begin{array}{l}2 \cdot 2 \\
2 \cdot 25\end{array}$ \\
\hline Fuel & & Butterworth & $2 \cdot 5$ \\
\hline $\begin{array}{l}\text { Journal of Electronics } \\
\text { Chemical Abstracts }\end{array}$ & $\begin{array}{l}\text { U.K. } \\
\text { U.S.A. }\end{array}$ & $\begin{array}{l}\text { Taylor and Francis } \\
\text { American Chemical society }\end{array}$ & $\begin{array}{l}5 \cdot 8 \\
3 \cdot 0\end{array}$ \\
\hline $\begin{array}{l}\text { Journal of Inorganio } \\
\text { and Nuclear Chemisiry }\end{array}$ & U.K. & Pergamon Press & 36 \\
\hline Tetrahedron & U.K. & Pergamon Press & $4 \cdot 0$ \\
\hline $\begin{array}{l}\text { Physics and Chemistry } \\
\text { of Solids } \\
\text { Chemieal Engineering }\end{array}$ & U.K. & Pergamon Press & $t \cdot 1$ \\
\hline Scienc & U.t. & on Press & $5 \times$ \\
\hline Reactor Science & U. $\overline{\mathbf{K}}$. & Pergamon Press & $8 \cdot 9$ \\
\hline
\end{tabular}

They believe that a reduction in costs leads to increased circulation of seientifie journals.

\section{Preservation of Documents}

A study by W. K. Wilson and B. W. Forshee, of the National Bureau of Standards, made at the request of the National Archives, the United States Army Map Service, the Library of Congress and the Virginia State Library, of the preservation of documents by lamination has shown that pre-treatment with alkaline media is desirable if the paper contains an appreciable amount of acid (Monograph No. 5 . 